\title{
Pathogenicity Evaluation of Bipolaris oryzae Isolates on Egyptian Rice Cultivars
}

\author{
Sherihan M. M. Bekheet ${ }^{1}{ }^{2}$, Ahmed F. El-Bebany ${ }^{1}$, Sayed S. Aboshosha ${ }^{1}$, Mohsen M. Saleh² and
}

Amany H. M. Shams ${ }^{1}$

\begin{abstract}
The aim of this study was to evaluate the pathogenicity of Bipolaris oryzae, the causal agent of brown spot disease on Egyptian rice cultivars. Sample of rice were collected from 10 cultivars namely (Sakha 101, Sakha 104, Sakha 106, Giza 176, Giza 177, Giza 178, Giza 182, Egyptian hybrid and Egyptian Yasmin). Fungal genera were recovered from the rice samples. These fungi were identified as (Curvularia lunata, Asprgillus niger, Asprgillus flavus, Penicillium sp., Trichoderma, Alternaria alternata, Bipolaris oryzae, Fusarium verticillioides, Fusarium chlamydosporum, Rhizopus oryzae, Curvularia tuberculate, Bipolaris hawaiiensis, Cephaliophora tropica and Negrospora sp.). Out of the fourteen fungi, B. oryzae was characterized as one of the highest frequently exists fungus. Ten isolates of $B$. oryzae were investigated in terms of spore dimension, number of septa of conidia, linear growth and culture color. These ten $B$. oryzae isolates were used in the pathogenicity test on five commercial rice cultivars (Sakha 108, Sakha super 300, Giza 177, Giza 182 and Egyptian hybrid. The disease severity was assessed 7days after inoculation, 21-days-old rice plants. The most aggressive $B$. oryzae isolates were B.o10, B.o7, B.09 and B.o8. On the other hand, the lowest aggressive once were B.o2, and B.o1. Screening of the B. oryzae isolates on the commercial rice cultivars in the rice cultivation area in Egypt could help develop prediction plane of brown spot disease, ultimately, facilitate the most proper decision for rice cultivars to be cultivated.
\end{abstract} Egypt

Key words: Rice, Pathogenicity , Bipolaris oryzae,

\section{INTRODUCTION}

Rice (Oryza sativa L.) is the world's third most widely grown grain after corn and wheat. In the Middle East, Egypt is the major rice producer. In the 7 th century, rice cultivation was most likely brought to Egypt. Rice is the second most essential cereal after wheat in terms of nutritional importance (RRTC, 2014). According to the FAO, in Egypt, rice harvest area in 2019 was 799.032 hectares, with a total production of 6.690 million tonnes. Rice grain yield/unit area is decreasing as a result several rice diseases (FAO 2019).
Under the local Egyptian climate, many diseases and disorders affecting rice plants during the growing season, influencing grain yield and quality. Rice grain discoloration is a complex disease caused by fungal plant pathogens infecting the glumes, kernels, or both. Bipolaris oryzae, Alternaria padwickii, Pyricularia oryzae, Fusarium verticillioidies, Fusarium grminearum, Curvularia spp, Nigrospora oryzae, and Epicoccum nigrum have all been linked to grain discoloration (Ou, 1985, Ahn, et al. 2005; Phat et al., 2005).

Brown spot, caused by Bipolaris oryzae Shoemaker (Heliminthosporium oryzae Breda de Hann, teleomorph Cochliobolus miyabeanus), is a severe seedborne and seed transmitted disease of rice that affects rice growers worldwide. In Egypt, the disease comes in the second rank after blast disease (El-Wahsh 1997). The pathogen affects the crop from seedling to milk stage; brown spot symptoms occur in the early stages of development as a small blight on seedlings, and later developed as a large blight. Brown spot signs occur in the early stages of development as the minute blight of seedlings and later coleoptile, leaf blade, leaf sheath, and glume, with leaf blades and glumes being the most common. On leaves, typical spots are brown with a grey or whitish center, cylindrical or oval-shaped, and have a yellow halo, while young spots are small, circular, and can appear as dark brown or purplish brown dots. The leaf dries up until some spots coalescence. The scorched appearance of the affected nursery, caused by the death of seedlings and a drastic reduction in grain weight and yield, may also be recognized from a distance (Agarwal et al. 1989). It can reduce yield and affect grain quality and quantity (El-Shafey et al., 2018). Brown spot is one of the most common diseases that cause spots on grains, and it can reduce grain weight by $12-30 \%$ and the number of whole grains per panicle by $18-22 \%$, in addition to causing broken grains, reduced viability, and consistency loss, and creating dark plaster-like grains (El-Shenawy et al., 2018). The favorable conditions, it can cause up to $50 \%$ of damage and up to $35 \%$ of loss of germination of the seeds.

DOI: 10.21608/asejaiqjsae.2021.185714

${ }^{1}$ Department of Plant Pathology, Faculty of Agriculture, Alexandria

University, El-Shatby 21545, Alexandria, Egypt

${ }^{2}$ Plant Pathology Institute, Agriculture Research Center, 12619, Giza, Egypt

* sheri_2222@yahoo.com

Received June 20, 2021, Accepted, July 25, 2021. 
The objectives of the present investigation were to isolate and identify fungal pathogens from rice grain varieties showing grain discoloration symptoms based on morphological characteristics as well as evaluating the pathogenicity of the selected isolates on Egyptian rice cultivars.

\section{MATERIALS AND METHODS}

\section{Rice samples:}

Rice grain samples were collected from the Research Institute Center, Sakha, Kafr El Sheikh, Field Crops Research Institute (FCRI), Agricultural Research Center (ARC). The seeds collected from ten rice cultivars (Sakha 101, Sakha 104, Sakha 106, Sakha 107, Giza 176, Giza 177, Giza 178, Giza 182, Egyptian hybrid and Egyptian Yasmin).

\section{Isolation and purification of fungi from rice seeds}

Rice seed cultivars were assayed for the presence of fungi by Agar plate Methods following the rules of International Seed Testing Association (ISTA, 2001). Briefly, two hundred rice grains from each cultivar were washed in running tap water, surface sterilized in sodium hypochlorite $(1 \%)$ for two minutes, then rinsed in sterile water to test the presence of fungus. The grains were surface sanitized, then dried on sterilize filter paper before plating on potato dextrose agar medium (PDA) .The plates were laid out in a completely random pattern with ten replications (10 plates / replication) and incubated at $25^{\circ} \mathrm{C}$ for 5 days. The developed fungi were sub- cultured, then purified by single spore isolation, the isolated fungi were sub-cultured on PDA slants and kept at $4^{\circ} \mathrm{C}$ (Ilyas \& Navaid, 1995). The different fungal isolates were identified based on the culture morphological characteristics and microscopic examination. Temporary slides were prepared and observed using compound light microscope for proper identification. The fungal isolates were identified to species level, wherever possible, following the appropriate Keys (Barnet, 1962; Booth, 1971; Agarwal, 1989; Mew \& Misra, 1994; Mew \& Gonzales, 2002; Manamgoda et al., 2011). The data on frequency of isolated fungi from seeds of different rice cultivar were recorded using the following formula:

Number of seeds colonized by a fungus

Colonization $\%=\frac{}{\mathrm{X}} \mathrm{X} 100$

Total number of seeds studied

\section{Fungal identification}

Morphological characteristics was used for identifying the obtained fungal isolates as described in the following procedures:

\section{Culture examination and microscopic characteristics:}

Fungal isolates were identified as, Alternaria $s p$., Aspergillus, Bipolaris, Curvularia, Fusarium, Penicillium, Rhizopus, Negrospora, Cephaliophora and Trichoderma comprising fourteen species were found to be associated with the seed samples. Pathogenic and saprophytic fungi were counted and identified using different magnifications of a stereomicroscope and were identified by colony growth, color, sporulation type and available literature (Booth, 1971; Sutton, 1980; Mathur $\&$ Kongsdal, 2003).

\section{Morphological characterization of ten isolates of $B$.} oryzae:

Based on the microscopic examination ten isolates of $B$. oryzae were selected for colony morphological examination. Morphological characterizations of ten culture isolates $B$. oryzae carried out on PDA by incubation at $28 \pm 2^{\circ} \mathrm{C}$ for 7 days. Colony growth, mycelial color, sporulation, conidium size, shape, color and conidiophore characters were observed. All ten isolates were grown in PDA medium for 5- 7 days. A 9 $\mathrm{mm}$ mycelial disc from 7 days old culture was placed at center of sterilized glass slide under aseptic condition on moist sterile Petri-plate and incubated at $25 \pm 2^{\circ} \mathrm{C}$ for 7 days with alternate $12 \mathrm{hrs}$. light and dark period. After 5 days of incubation, the spore suspension was collected using sterile distilled water and examined using compound microscope (Kumari et al., 2015).

\section{Pathogenicity test}

\section{Fungal inoculum preparation}

The confirmed $B$. oryzae by microscopic examination and culture characteristic was used for brown spot disease evaluation. Ten isolates of $B$. oryzae were selected and cultured on PDA at $25{ }^{\circ} \mathrm{C}$ under $12 \mathrm{~h}$ light and $12 \mathrm{~h}$ darkness conditions for 14 days, then conidial suspensions were prepared by scraping the surface of culture plates and washing in sterile water containing one drop of Tween 20 . Then the B. oryzae suspension was filtered through 2 layers of cheese cloth. Concentration of conidia was adjusted to $5 \times 10^{4}$ using a haemocytometer and used for rice plants inoculation.

\section{Rice cultivars}

Thirty days old rice plants were used as host plants. The tested five cultivars were Sakha 108, Sakha super 300, Giza 177, Giza 182, and Egyptian hybrid. The rice plants were sprayed with conidial suspension of selected isolates. Control rice plants were sprayed with distilled water containing a drop of Tween 20 .

\section{Rice inoculation and disease assessment}

The plants were covered with transparent plastic sheets to provide adequate humidity and kept at room 
Table 1. Scale for foliar disease assessment (IRRI, 2002)

\begin{tabular}{|c|c|c|}
\hline Disease rating & Disease severity & Host response \\
\hline $\begin{array}{l}\text { Disease intensity } \% \\
\quad=0\end{array}$ & Spots are not present. & Highly resistant (HR) \\
\hline 1 & Small brown speaks of pin point size on lower leaves. & Resistant (R) \\
\hline 2 & $\begin{array}{l}\text { Small roundish necrotic brown spots, about } 1-2 \mathrm{~mm} \text { in diameter, } \\
\text { with a distinct brown margin. Spots are mostly focused on lower } \\
\text { leaves. }\end{array}$ & $\begin{array}{l}\text { Moderately resistant } \\
\text { (MR) }\end{array}$ \\
\hline 3 & $\begin{array}{c}\text { Spot type same as in 2, but significant number of spots on the } \\
\text { upper leaves. }\end{array}$ & $\begin{array}{l}\text { Moderately susceptible } \\
\text { (MS) }\end{array}$ \\
\hline 4 & $\begin{array}{c}\text { Typical susceptible brown spot, } 3 \mathrm{~mm} \text { or larger infecting less } \\
\text { than } 4 \% \text { of the leaf area. }\end{array}$ & $\begin{array}{l}\text { Moderately susceptible } \\
\text { (MS) }\end{array}$ \\
\hline 5 & $\begin{array}{c}\text { Typical susceptible brown spot, } 3 \mathrm{~mm} \text { or larger infecting 4-10\% } \\
\text { of the leaf area. }\end{array}$ & $\begin{array}{l}\text { Moderately susceptible } \\
\text { (MS) }\end{array}$ \\
\hline 6 & $\begin{array}{c}\text { Typical susceptible brown spot, } 3 \mathrm{~mm} \text { or larger infecting 11-25 } \\
\text { \% of the leaf area. }\end{array}$ & Susceptible (S) \\
\hline 7 & $\begin{array}{l}\text { Typical susceptible brown spot, } 3 \mathrm{~mm} \text { or larger infecting } 26- \\
50 \% \text { of the leaf area. }\end{array}$ & Susceptible (S) \\
\hline 8 & $\begin{array}{l}\text { Typical susceptible brown spot, } 3 \mathrm{~mm} \text { or larger infecting 51- } \\
75 \% \text { of the leaf area. }\end{array}$ & $\begin{array}{l}\text { Highly susceptible } \\
\text { (HS) }\end{array}$ \\
\hline 9 & $\begin{array}{c}\text { Typical susceptible brown spot, } 3 \mathrm{~mm} \text { or larger infecting more } \\
\text { than } 75 \% \text { of the leaf area. }\end{array}$ & $\begin{array}{l}\text { Highly susceptible } \\
\text { (HS) }\end{array}$ \\
\hline
\end{tabular}

temperature. The inoculated plants were observed seven days after inoculation. Disease scoring was done using standard disease rating scale of IRRI (2002) as follow (Table 1).

Koch's Postulates were completed by re-isolating the pathogen from the inoculated plants to prove the pathogenicity of 10 isolates of $B$. oryzae under greenhouse conditions.

Pathogenicity of $B$. oryzae isolates were evaluated and compared based on the Disease Index formula (Gao et al., 2011).

Disease Index $(\%)=[\Sigma(\mathrm{r} \times \mathrm{nr}) /(9 \times \mathrm{Nr})] \times 100$

where $\mathrm{r}=$ rating value, $\mathrm{nr}=$ number of infected leaves with a rating of $r$ and

$\mathrm{Nr}=$ total number of leaves tested.

\section{Statistical analysis}

The pathogenicity test was conducted in a completely randomized design where fungal isolates and pots were considered as treatments and replicates, respectively. Four pots were used for each isolate, and each pot contained twenty-five plants. Data analysis was done using (SAS 1997) software version 6.12.

\section{RESULTS AND DISCUSSION}

\section{Fungal isolates recovered from rice samples}

Fourteen fungal isolates were recovered for the rice samples, (Table 2) these fungal isolates are:

Curvularia lunata, Asprgillus niger, A.flavus, Penicillium sp., Trichoderma sp., Alternaria alternata, Bipolaris oryzae, Fusarium verticillioides Fusarium chlamydosporum, Rhizopus oryzae, Curvularia tuberculate, B. hawaiiensis, Cephaliophora tropica and Negrospora $s p$. were isolated and identified from seeds of ten rice varieties (Sakha 101, Sakha 104, Sakha 106, Sakha 107, Giza 176, Giza 177, Giza 178, Giza 182, Egyptian hybrid and Egyptian Yasmin). The different fungal species were associated with grain discoloration symptoms. Based on their morphological characteristics, colony morphology, conidial, conidiophores and growth pattern (Figure 1).

The frequencies of the isolated fungi were Asprgillus niger (2-10.5\%), A. flavus (1-9.5\%), Penicillium sp. (0.5-2.5\%), Trichoderma (0.5-5.5 \%) Alternaria alternata (3.5-4.5\%), B. oryzae (3.5-9\%), B. hawaiiensis (5.5\%) Curvularia lunata (6\%), Fusarium verticillioides (3-7\%) and Rhizopus oryzae (1-9.5\%). The other species; Fusarium verticillioides, Curvularia lunata, Negrospora sp, and Cephaliophora tropica were found in low frequency. 

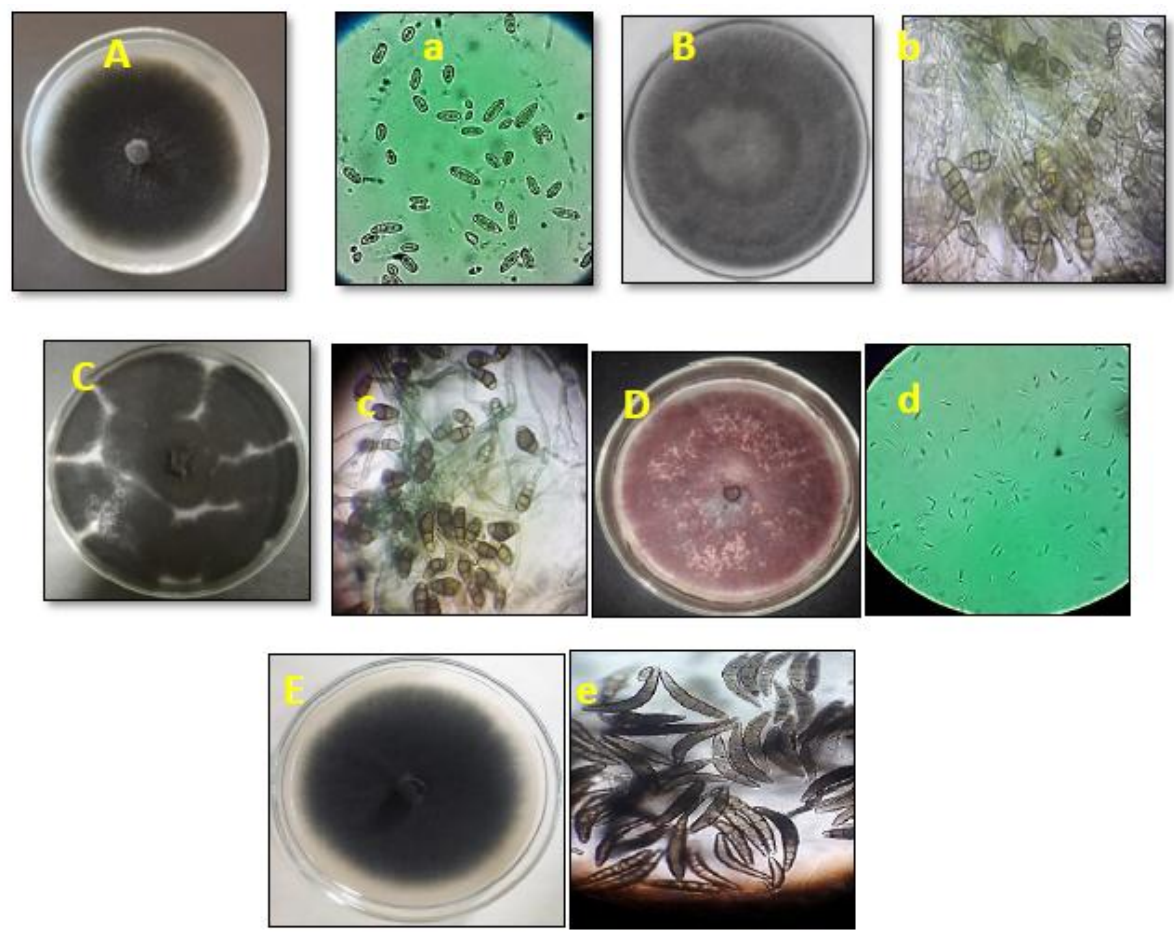

Figure 1.Morphological characteristics of rice seed borne pathogens and its conidiospores (with small letter) from rice grains (A,a) Bipolaris hawaiiensis, (B,b) Alternaria alternata, (C,c) Curvularia lunata, (D,d) Fusarium verticillioides and (E,e) Bipolaris oryzae .

Table 2.(\%) Frequency of isolated fungi from seeds of different rice varieties

\begin{tabular}{|c|c|c|c|c|c|c|c|c|c|c|}
\hline Fungal isolate & $\begin{array}{c}\text { Sakha } \\
101\end{array}$ & $\begin{array}{c}\text { Sakha } \\
104\end{array}$ & $\begin{array}{c}\text { Sakha } \\
106\end{array}$ & $\begin{array}{c}\text { Sakha } \\
107\end{array}$ & $\begin{array}{c}\text { Giza } \\
176\end{array}$ & $\begin{array}{c}\text { Giza } \\
177\end{array}$ & $\begin{array}{c}\text { Giza } \\
178\end{array}$ & $\begin{array}{c}\text { Giza } \\
182\end{array}$ & $\begin{array}{c}\text { Egyptian } \\
\text { hybrid }\end{array}$ & $\begin{array}{l}\text { Egyptian } \\
\text { Yasmine }\end{array}$ \\
\hline Asprgillus niger & 6 & 7 & 3 & 7.5 & 4.5 & 10.5 & 5 & 3.5 & 2.5 & 2 \\
\hline Asprgillus flavus & 0 & 1.5 & 1 & 9.5 & 2.5 & 2 & 2 & 2 & 0 & 1.5 \\
\hline penicillium $s p$ & 2.5 & 0.5 & 0.5 & 1.5 & 2 & 0 & 1 & 0.5 & 0 & 0 \\
\hline Trichoderma $s p$ & 0 & 0.5 & 0 & 5.5 & 1.5 & 0 & 0 & 1 & 1 & 2.5 \\
\hline Alternaria alternata & 3.5 & 0 & 0 & 0 & 0 & 0 & 0 & 4.5 & 0 & 0 \\
\hline Bipolaris oryzae & 3.5 & 7 & 3.5 & 9 & 8 & 6.5 & 0 & 3.5 & 0 & 0 \\
\hline Curvularia lunata & 0 & 0 & 0 & 0 & 0 & 0 & 0 & 6.5 & 0 & 0 \\
\hline $\begin{array}{l}\text { Fusarium } \\
\text { chlamydosporum }\end{array}$ & 0 & 0 & 0 & 0 & 0 & 2 & 0 & 0 & 0 & 0 \\
\hline $\begin{array}{l}\text { Fusarium } \\
\text { verticillioides }\end{array}$ & 0 & 0 & 3 & 7 & 0 & 0 & 0 & 0 & 0 & 0 \\
\hline Rhizopus oryzae & 3.5 & 2 & 9.5 & 1.5 & 2.5 & 3 & 6.5 & 1 & 3 & 0 \\
\hline $\begin{array}{l}\text { Curvularia } \\
\text { tuberculate }\end{array}$ & 0 & 0 & 0 & 0 & 0 & 2 & 0 & 1 & 0 & 0 \\
\hline $\begin{array}{l}\text { Bipolaris } \\
\text { hawaiinses }\end{array}$ & 0 & 0 & 0 & 5.5 & 0 & 0 & 5.5 & 0 & 0 & 0 \\
\hline Negrospora oryzae & 0 & 0 & 0 & 1.5 & 0 & 1.5 & 0 & 0 & 0 & 2.5 \\
\hline $\begin{array}{l}\text { Cephaliophora } \\
\text { tropica }\end{array}$ & 0 & 0.5 & 0 & 0 & 0 & 2.5 & 0 & 0 & 0 & 0 \\
\hline
\end{tabular}


The present study was focused on the survey of seed-borne fungi associated with some Egyptian rice cultivars. These results were in coherence with those of many research groups around the world (Imolehin, 1987; Kim and Lee, 1989; Odebunmi, 1989; Wahid et al., 1993; Khan et al., 2000; Javaid et al., 2002, Ibiam et al., 2006؛ Mohamed \& Gomaa 2019). Many of the isolated fungi have been reported to be associated with seeds of other crops (Tsopmbeng \& Fomengia, 2015). Some of them are also known to cause seed rot, decrease seed germination and cause pre-and postdamping off and seedling death (Al-kassam \& Monawar, 2000) In this study, Pyricularia oryzae, known for a long time as rice seed-borne fungus (Manandadhar et al., 1998) was not isolated from any of the rice cultivars, confirming the statement by (Signaboubo, S., et al., 2016) who found that this fungus was less common on rice seeds.

\section{Morphological variability of $B$. oryzae isolates}

All the isolates studied showed significant differences in growth and colony characters. The variation in morphological characters of different isolates indicated that B. oryzae isolate Bo1, Bo2, Bo9 and Bo10 showed dark greyish colony, light greyish colour colony (Bo3 and Bo5), olive colony (Bo4, Bo6, Bo7 and Bo8).
In agreement with Meghana and Hiremath (2019), excellent sporulation was exhibited by isolates Bo1, Bo7, Bo9, and Bo10, however good sporulation was observed in Bo4, Bo5, Bo6 and Bo8 whereas, poor sporulation was noticed in $\mathrm{Bo} 2$ and Bo3. Maximum size of conidia was observed in Bo10 (length- $117 \mu \mathrm{m}$ and width-10 $\mu \mathrm{m})$ followed by Bo8 $(114.25 \times 6.75 \mu \mathrm{m})$, Bo9 $(113 \times 10.75 \mu \mathrm{m})$ and Bo7 $(110 \times 8.5 \mu \mathrm{m})$. Minimum size of conidia was found in Bo1 $(64 \times 12.5 \mu \mathrm{m})$. Isolate Bo9 showed maximum number of septa with 11 septa followed by Bo10 with 10 septa, Bo7 with 9 septa and minimum number of septa (5-7) were recorded in Bo1, Bo2, Bo3, Bo4, Bo5, Bo6 and Bo8.

Meghana \& Hiremath (2019) reported that mycelium was fluffy, cottony, grey olivaceous with brownish tinge and conidia were curved, fucoid or obclavate, cylindrical, pale to mid golden brown with 612 septations. Results are also in agreement with (Arshad et al., 2013) who reported that, mycelium appeared to be grey to dark greenish grey and conidia were dark brown to olivaceous brown, straight or curved with 6-14 septations. Kumari et al., (2015) reported that cultural characters (blackish, grey, white color mycelium with fluffy or cottony growth), spore dimension with length 5.34 to $7.48 \mu \mathrm{m}$ and width with 4.10 to $5.51 \mu \mathrm{m}$ and sporulation.

Table 3.Cultural characteristics of the ten seven days old isolates of Bipolaris oryzae

\begin{tabular}{|c|c|c|c|c|c|c|c|}
\hline \multirow[t]{2}{*}{$\begin{array}{l}\text { Isolate } \\
\text { code }\end{array}$} & \multirow[t]{2}{*}{ cultivar } & \multicolumn{2}{|c|}{$\begin{array}{c}\text { conidia } \\
\text { dimension }(\mu \mathrm{m}) * * \\
\end{array}$} & \multirow{2}{*}{$\begin{array}{l}\text { Number of } \\
\text { septa in } \\
\text { conidia }\end{array}$} & \multirow[t]{2}{*}{$\begin{array}{c}\text { Linear } \\
\text { growth }(\mathrm{cm})\end{array}$} & \multirow[t]{2}{*}{ Sporulation* } & \multirow[t]{2}{*}{$\begin{array}{c}\text { Culture } \\
\text { color }\end{array}$} \\
\hline & & Length & Width & & & & \\
\hline B.o 1 & S 106 & $64 \mathrm{i}$ & $12.5 \mathrm{bc}$ & $7 \mathrm{~d}$ & $7.73 \mathrm{~d}$ & +++ & Dark Gray \\
\hline B.o 2 & G182 & $83.75 \mathrm{e}$ & $13.5 \mathrm{~b}$ & $6 \mathrm{e}$ & $7.0 \mathrm{f}$ & + & Dark Gray \\
\hline B.o 3 & S106 & $72 \mathrm{~g}$ & $12.25 \mathrm{c}$ & $7 \mathrm{~d}$ & $7.95 \mathrm{c}$ & + & Light Gray \\
\hline B.o 4 & G176 & $68 \mathrm{~h}$ & $16.25 \mathrm{a}$ & $5 \mathrm{f}$ & $8.98 \mathrm{a}$ & ++ & Olive \\
\hline B.o 5 & S101 & $75.75 \mathrm{f}$ & $12.5 \mathrm{bc}$ & $5 \mathrm{~d}$ & $8.15 \mathrm{~b}$ & ++ & Light Gray \\
\hline B.o 6 & S107 & $95.75 \mathrm{~d}$ & $7 \mathrm{f}$ & $7 \mathrm{~d}$ & $9.0 \mathrm{a}$ & ++ & Olive \\
\hline B.o 7 & S101 & $110 \mathrm{c}$ & $8.5 \mathrm{e}$ & $9 \mathrm{c}$ & $7.22 \mathrm{e}$ & +++ & Olive \\
\hline B.o 8 & G177 & $114.25 \mathrm{ab}$ & $6.75 \mathrm{f}$ & $7 \mathrm{~d}$ & $8.96 \mathrm{a}$ & ++ & Olive \\
\hline B.o 9 & G182 & $113 \mathrm{bc}$ & $10.75 \mathrm{~d}$ & $11 \mathrm{a}$ & $4.95 \mathrm{~h}$ & +++ & Dark gray \\
\hline B.o 10 & G177 & $117 \mathrm{a}$ & $9.75 \mathrm{~d}$ & $10 \mathrm{~b}$ & $6.55 \mathrm{~g}$ & +++ & Dark Gray \\
\hline
\end{tabular}


Pathogenicity of $B$. oryzae isolates on ten rice cultivars:

The results of severity index of $B$. oryzae isolates recorded in (Tables 4 and 5) show that the aggressiveness of the isolates varies according to rice cultivar. However, some isolates were aggressive to almost all the tested rice cultivars. Others were more or less aggressive, depending on the varieties. Data showed that the Egyptian rice cultivar Sakha 108 was the most resistant cultivar to brown spot caused by B.oryzae. On the other hand the cultivar Giza 177 was the most susceptible cultivar for infection with $B$. oryzae isolates. These results are in agreement with Hammoud et al., (2020).

The results showed that $B$. oryzae isolate Bo10 was more pathogenic followed by isolates Bo7 and then Bo9 on the other side. B. oryzae isolate $\mathrm{Bo} 2$ was unable to cause infection, while B. oryzae isolates B.o1, Bo3, Bo4, Bo6 and Bo8 were moderately pathogenic to rice cultivars.

Infected rice leaves were recognized with the appearance of lesions that are initially dark brown to purple-brown, light brown to gray center and reddishbrown margin on the leaves (Figure 2).

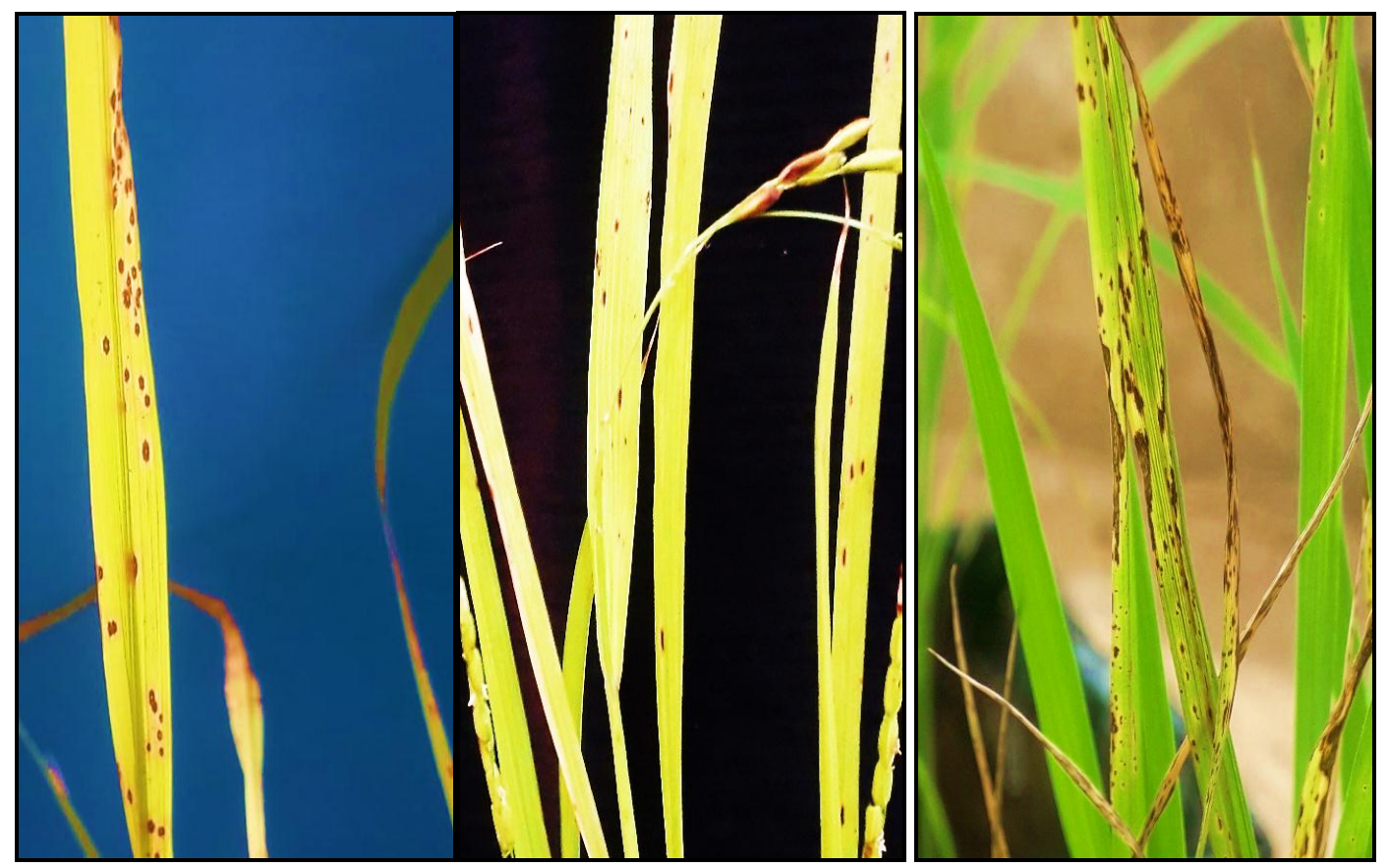

Figure 2. Brown spot symptoms in the artificially inoculated leaves

Table 4 .Reaction of the five tested rice cultivars seven days after inoculation with $B$. oryzae isolates

\begin{tabular}{cccccc}
\hline Cultivar & Sakha 108 & $\begin{array}{c}\text { Sakha super } \\
\text { Isolate code }\end{array}$ & Giza 177 & Giza 182 & $\begin{array}{c}\text { Egyptian } \\
\text { hypride }\end{array}$ \\
\hline B.o 1 & $\mathrm{HR}$ & $\mathrm{R}$ & $\mathrm{R}$ & $\mathrm{R}$ & $\mathrm{R} *$ \\
B.o 2 & $\mathrm{HR}$ & $\mathrm{HR}$ & 0 & $\mathrm{HR}$ & $\mathrm{HR}$ \\
B.o 3 & $\mathrm{HR}$ & $\mathrm{HR}$ & $\mathrm{R}$ & $\mathrm{HR}$ & $\mathrm{R}$ \\
B.o 4 & $\mathrm{HR}$ & $\mathrm{R}$ & $\mathrm{R}$ & $\mathrm{R}$ & $\mathrm{HR}$ \\
B.o 5 & $\mathrm{HR}$ & $\mathrm{HR}$ & $\mathrm{R}$ & $\mathrm{HR}$ & $\mathrm{R}$ \\
B.o 6 & $\mathrm{R}$ & $\mathrm{R}$ & $\mathrm{S}$ & $\mathrm{R}$ & $\mathrm{R}$ \\
B.o 7 & $\mathrm{MR}$ & $\mathrm{MS}$ & $\mathrm{S}$ & $\mathrm{MS}$ & $\mathrm{MR}$ \\
B.o 8 & $\mathrm{R}$ & $\mathrm{R}$ & $\mathrm{MS}$ & $\mathrm{MR}$ & $\mathrm{R}$ \\
B.o 9 & $\mathrm{MR}$ & $\mathrm{MR}$ & $\mathrm{S}$ & $\mathrm{MR}$ & $\mathrm{MR}$ \\
B.o 10 & $\mathrm{MR}$ & $\mathrm{S}$ & $\mathrm{S}$ & $\mathrm{S}$ & $\mathrm{MR}$ \\
\hline
\end{tabular}

* HR = (Highly Resistant) $\mathrm{R}=$ (Resistant) $\mathrm{MR}=$ (Moderately Resistant) $\mathrm{S}=$ (Susceptible)

HS = (Highly Susceptible)

The assessment was done according to the IRRI, 2002 scale. 
Table 5. Disease severity index (SI) of Bipolaris oryzae isolates on the five rice varieties

\begin{tabular}{ccccccc}
\hline Cultivar & Sakha 108 & $\begin{array}{c}\text { Sakha super } \\
\mathbf{3 0 0}\end{array}$ & Giza 177 & Giza 182 & $\begin{array}{c}\text { Egyptian } \\
\text { hypride }\end{array}$ & Isolates mean* \\
Isolate code & \multicolumn{7}{c}{} & & & & \\
\hline B.o 1 & 0 & 0.89 & 2.22 & 0.22 & $0.33 *$ & $0.732 \pm 0.89$ \\
B.o 2 & 0 & 0 & 0 & 0 & 0 & $0 \pm 0$ \\
B.o 3 & 0 & 0 & 2.88 & 0.44 & 1.33 & $0.93 \pm 1.22$ \\
B.o 4 & 0 & 0.67 & 2.67 & 1.56 & 0 & $0.98 \pm 1.14$ \\
B.o 5 & 0 & 0 & 2.33 & 0 & 2 & $0.866 \pm 1.19$ \\
B.o 6 & 2.88 & 3.33 & 4.33 & 4.33 & 3.33 & $3.64 \pm 0.66$ \\
B.o 7 & 12.44 & 20 & 41.33 & 20 & 13.33 & $21.42 \pm 11.69$ \\
B.o 8 & 2.88 & 4.33 & 10 & 6.66 & 3.33 & $5.44 \pm 2.94$ \\
B.o 9 & 6.66 & 15.33 & 30.33 & 15.33 & 14.88 & $16.51 \pm 8.57$ \\
B.o 10 & 9.33 & 31.33 & 39.33 & 35.33 & 15.33 & $26.13 \pm 13.08$ \\
Cultivars & $3.42 \pm 4.54$ & $7.59 \pm 10.92$ & $13.54 \pm 16.62$ & $8.39 \pm 11.76$ & $5.39 \pm 6.24$ & \\
mean & & & & & & \\
\hline
\end{tabular}

Means of 100 leaves.

*SI was calculated according to (Gao et al., 2011)

In general, the new rice cultivar Sakha108 exhibited significant advantages over the widespread cultivars. The new rice cultivar has higher yield potential compared with Giza 177 with excellent grain quality, yet with shorter growth duration. Furthermore, the new cultivar is blast resistant and hence, it could be ideal candidate to replace Sakha101and Giza 177 gradually. This will significantly help to improve /maintain varietal policy with new high yielding and biotic stress resistant rice cultivars to replace old/susceptible rice cultivar. In Egypt Sakha 108 is a model of continuous flow of new rice varieties to cope with highly variable biotic stress agent such as blast fungus. The results of the new cultivar demonstrate the power of backcross breeding in developing blast resistant rice genotypes using susceptible parent and suitable blast resistance donor. This will indeed enhance productivity per unit area and minimize the negative impact of blast disease and brown spot caused by B.oryzae on national rice production. However, the tolerance of these rice cultivars to abiotic stress such as salinity should be considered. Attaining such policy could greatly help in achieving food security of such strategic crop.

\section{REFERENCES}

Agarwal, P. C., C. N. Mortensen and B. Mathur. 1989. Seedborne diseases and seed health testing of rice. Technical bulletin No. 3, Phytopathlogical papers 30: 106.

Ahn, I.P., S. Kim, S., Kang, S.C., Suh and Y.H. Lee. 2005. Rice defense mechanisms against Cochliobolus miyabeanus and Magnaporthe grisea are distinct. Phytopathology.95: 1248-1255.

Al-Kassam, M.Y., and M.N. Manawar. 2000. Seed-borne fungi of some vegetable seeds in Gazan Province and their chemical control. Saudi J. Biol. Sci., 7 (2): 179-185.
Arshad, H., M.I. Hussain, N. Ali, S. Khan, J.A. Saleem and M.M. Babar. 2013. Behavior of Bipolaris oryzae at different temperatures, culture media, fungicides and rice germplasm for resistance. Pak. J. Phytopathol., 25 (01): 84-90.

Barnett, H. L. 1962. Illustrated genera of imperfect fungi, $2^{\text {nd }}$ edition. Minneapolis, Minnesota, USA. 44(1):143p.

Booth, C. 1971. The genus Fusarium Commonwealth. Mycological Institute, Kew, Surrey, England, 236p.

Ellis, M.B. 1976. More dematiaceous hyphomycetes. Commonwealth Mycological Institute, Kew, Surrey, England,507p.

El-Shafey, R., A. S. Attia, K. A., Mostafa, Fatma A. and Rabab M. Elamawi, 2018. Incidence and molecular identification of Cochliobolus carbonum as causal organism of rice seedling blight. Beni-Suef University Journal of Basic and Applied Sciences. 7(4): 652-662.

El-Shenawy, M. M., W.H., Elgamal, G. B. Anis and F. Awad. 2018. Combined genetic analysis of brown spot (Helminthosporium oryzae) disease for developed hybrid combinations and their parental lines in hybrid rice. Sustainable Food Production. 1: 37-48.

El-Wahsh, S.M. 1997. Studies on both brown spot and blast diseases of rice in Egypt. Ph.D. thesis, Fac. of Agric., kafr EL-Sheikh, Tanta Univ. Egypt.

FAO STAT, 2019. Food and Agriculture Organization of the United Nations statistic division. (Online) Available from: http://. www.fao.org/faostas.

Gao, D., K. Cai, and J. Chen. 2011. Silicon enhances photochemical efficiency and adjusts. mineral nutrient absorption in Magnaporthe oryzae infected rice plants. Acta Physiologiae Plantarum, 33 (3): 675-682.

Hammoud, S. A., M. I., Aboyessef, S. E. Sedeek and R. A. EL-Namaky. 2020. Sakha108 Egyptian rice variety Japonica type high yielding and resistant to blast. Journal of Plant Production11(11): 1153-1162. 
Ibiam, O.F.F., C.I., Umechuruba and A.E. Arinze. 2006. Seedborne fungi associated with seeds of rice (Oryzae sativa L.) in storage and from the field in Ohaozara and Onica Local Government areas of Ebonyi State. World J. Biotechnol., 7(1062): 1-72.

Ilyas, M.B. and M. S. Javaid. 1995. Mycoflora of basmati 385 seeds collected from Gujranwala, Hafizabad, Sheikhupura and Sialkot Districts. Pakistan Journal Phytopathology. 7(1): 50-52.

Imolehin, E.D. 1987. The rice seed multiplication centres in relation to seed-borne pathogens of rice: A case study of Ondo State Rice Multiplication Centers. Nigerian Journal of Plant Protection. 11:37-42.

IRRI. 2002. Standart Evaluation System for Rice. The International Rice Research Institute. Los Banos, Laguna, Philippines. 6(1):341-344.

ISTA (International Seed Testing Association). 2001. International Rules for Seed Testing. Seed Sci Technol., $335 \mathrm{p}$.

Javaid, M.S., A. Wahid, M. Idrees, M.A. Gill and A. Saleem. 2002. Seed Mycoflora studies in rice. Pak. J. Phytopathol., $14,132-134$.

Khan, T.Z. and M. A. Gill .2000. seed-borne fungi of rice from central Punjab and Their control. Pak. J. Phytopathol., (12): 12-14.

Kim, J.S. and Y.W. Lee. 1989. Identification of Aspergillus and Penicillium spp isolated from deteriorated rice. Korean J. Plants Pathol., 5:389-91.

Kumari, S., A., Kumar, and S. Rani. 2015. Morphological characterization of Bipolaris oryzae causing brown spot of paddy in Bihar. Int. Educ. Res. J., 1(5): 85-87.

Manamgoda, D. S., L. Cai, A. H. Bahkali, E. Chukeatirote and K.D. Hyde. 2011. Cochliobolus: an overview and current status of species. Fungal Divers. 51: 3- 42.

Manandadhar, H.K., H.J.L. Jorgensen, V. S. Petersen and S.B. Mathur. 1998. Seed-borne infection of rice by Pyricularia oryzae and its transmission to seedlings. Plant Dis., 82: 1093-1099.

Mathur, S. B. and O. Kongsdal. 2003. Common laboratory seed health testing methods for detection fungi, Published by the ISTA. P. O. Box 308, 08303-Bassersdrof. CHSwitzerland.
Meghana, S.N. and S.V. Hiremath. 2019. Cultural, morphological and molecular characterization of Bipolaris oryzae causing brown leaf spot of rice in Northern Karnataka. Journal of Pharmacognosy and Phytochemistry. 8(2): 1235-1239

Mew, T. W. and J.K. Misra. 1994. Manual of Rice Seed Health Testing. International Rice Research Institute, Los Banos, Laguna, Philippines. 1-120 pp.

Mew, T.W. and P. Gonzales. 2002. A Handbook of Rice Seed borne Fungi. International Rice Research Institutek, Manilla, Philippines. 1-82 pp.

Mohamed,A. and Gomaa,F.H2019. Molecular characterization and biological control of some rice seed-borne fungal pathogens. Journal of Phytopathology and Pest Management. 40-53.

Odebunmi, O.Y.K. 1989. Seed-borne pathogens of rice. Survival under experimental field conditions. Nigeria J. Plant Protection. 11: 1-8.

Ou, S.H. 1985. Rice Diseases. Kew UK. CAB International Mycological Institute.

Phat, C.T., N.T. Duong and L.T. Du. 2005. Influence of grain discoloration to seed quality. Omon rice. 13: 139-144.

Rice Research and Training Center (RRTC) 2014. Annual rice national campaign report of rice program. Rice Research and Training Center, Agricultural Research Center, Ministry of Agriculture and Land Reclamation, Egypt.

SAS, 1997. SAS/STAT User's Guide: Statistics, Version 6.12. SAS Institute Inc. Cary, NC., USA.

Signaboubo, S., G. T. Noumbo and K. J. Roger. 2016. Seedborne fungi associated with rice seeds varieties in Bongor, Chad Republic. International Journal of Current Microbiology and Applied Sciences. 5(12): 161-170.

Sutton, B. C. 1980. The Coelomycetes. Commonwealth Mycological Institute, Kew Surrey, England. 696p.

Tsopmbeng, N.G. 1994. Seed-borne fungi in African Yam bean (Sphenostylis stenocarpa Horchstex. A. Rich Harms) and their responses to fungicidal seed-treatment. MSc. Thesis, University of Nigeria, Nsukka, Nigeria. pp. 96.

Tsopmbeng, N.G., and D.N. Fomengia. 2015. Fungi associated with seeds of huckleberry (Solanum scabrum Mill.) grown in the western highlands of Cameroon. Journal of Agricultural Technology., 11(3): 791-801.

Wahid, A.M., M.U., H.Saleem, H. T. Khan and , A. Saleem. 1993. Seed-borne Mycoflora of rice. J. Agri. Res., 31: 95100. 
الملخص العربي

\section{تقييم القدرة الأمراضية لعزلات من الفطر Bipolaris oryzae علي بعض أصناف الأرز المصرية}

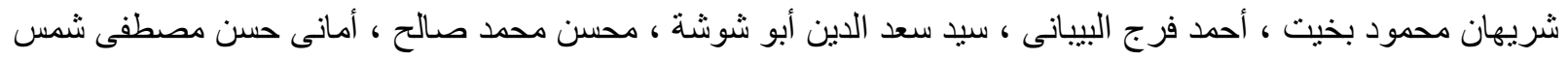

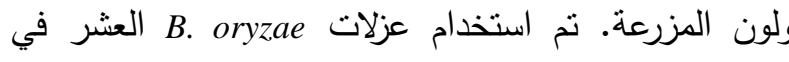

اختبار القدرة الإمراضية لخمسة أصناف من الأرز المصرى

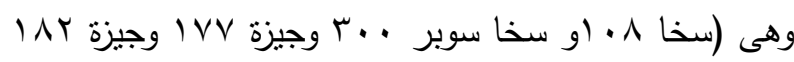

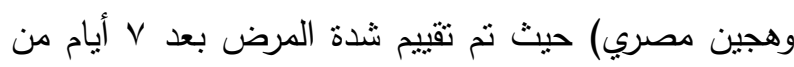

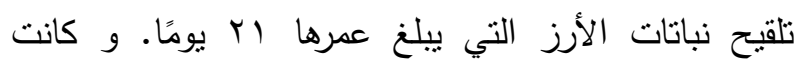
العزلات B.010 و B.07 و B.09 و B.08 هى الأكثر قدرة

إمراضية على التوالى. فى حين كانت العزلات B.o2 و B.o1 هى الأقل فى حدوث العدوى وعليه يمكن أن يساعد فحص عزلات B. oryzae على أصناف الأرز التجارية في مناطق زراعة الأرز في مصر في تطوير مستوى التتبؤ بمرض التبقع البنى ، ويساعد ذلك على اتخاذ القرار الأنسب

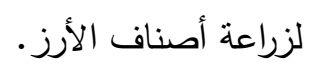

الكلمات المفتاحية: الأرز - مصر - التبقع البني بايبولارس اوريزي.
تهدف هذ الدراسة إلى تقييم القدرة الإمراضية للفطر Bipolaris oryzae ، المسبب الرئيسى لمرض التبقع البنى

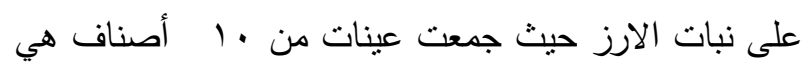

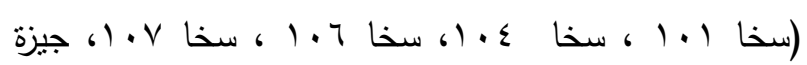

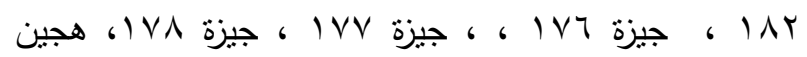
مصري و ياسمين مصري). حيث تم عزل ع ا جنس من جن

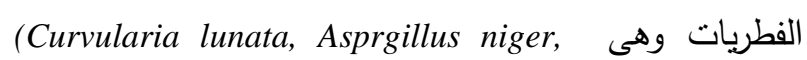
Asprgillus flavus, Penicillium sp., Trichoderma sp., Alternaria alternata, Bipolaris oryzae, Fusarium verticillioides, Fusarium chlamydosporum, Rhizopus oryzae, Curvularia tuberculate, Cephaliophora tropica, Negrospora oryzae and Bipolaris hawiophora).

B. من بين الفطريات الأربعة عشر ، تم تصنيف oryzae) حيث تم فحص عشر عزلات من فطر B. oryzae من حيث أبعاد الجراثثم الكونيديه وعدد حواجز الكونيديا ومعدل نمو 